\title{
AN ESSAY ON THE NEW PUBLIC DEFENDER FOR THE 21ST CENTURY
}

\author{
Charles J. Ogletree, JR.
}

\section{INTRODUCTION}

The problems facing indigents in criminal cases are well documented and have been so since the early part of this century. ${ }^{1}$ Nevertheless, funding for public defender services remains woefully inadequate. Studies at both the state and the federal level document the inadequacy of the resources available to those who are charged with the responsibility of defending the accused. ${ }^{2}$ Indeed, even the Supreme Court has noted the inability of public defenders to provide adequate counsel as a result of their limited resources and training. ${ }^{3}$ Yet the problems remain.

It is not possible to be certain why so little progress has been made in reforming the provision of public defender services in the face of so much evidence of the need for dramatic reform. Perhaps the failure of reform is a result of a general lack of appreciation of the fundamental societal values that public defender services further. Perhaps it is because the challenges facing public defenders, though well documented, are unknown to those in positions of authority. Or perhaps our leaders are aware of the importance of these services and of the problems facing public defenders but are unable to devise adequate solutions. This essay will address each of these potential explanations seriatim by attempting to articulate the importance of public defender services, examining the stresses facing the modern public defender, and drawing attention to a few particularly meritorious solutions that have been suggested by other scholars. This essay will then offer some anecdotal advice for public defenders and those designing public defender services based on my own experiences as a public defender in Washington, D.C.

\footnotetext{
Copyright 101995 by Law and Contemporary Problems

* Professor of Law and Director of the Criminal Justice Institute, Harvard University; formerly, Reporter for the Prado Committee, which drafted a detailed report to the Judicial Conference of the United States on the effectiveness of the Criminal Justice Act of 1964.

1. See, e.g., REginald HeBER SMITH, JUSTICE AND THE POOR (1919) (summarizing the plight of indigents in the criminal justice system).

2. See, e.g., Norman Lefstein, Financing The Right To Counsel: A National Perspective, 19 LOY. L.A. L. REV. 391, 392 (1985); Michael McConville \& Chester L. Mirsky, Criminal Defense of the Poor in New York City, 15 N.Y.U. REV. L. \& SoC. CHANGE 581, 694-95 (1987); Suzanne E. Mounts, Public Defender Programs, Professional Responsibility, and Competent Representation, 1982 WIS. L. REV. 473.

3. See, e.g., Jones v. Barnes, 463 U.S. 745 (1983) (role of appointed counsel in raising all issues suggested by clients on appeal); Polk County v. Dodson, 454 U.S. 312 (1981) (discussing, generally, some of the problems facing public defenders, as state actors, and their ability to effectively represent indigents charged with crimes).
} 
II

\section{Why Do We NeEd PUblic DefENDERS ANYWAY?}

The role of serving as a public defender is, by its nature, a difficult one. Public criticism of the legal profession in general is quite widespread, resulting in ongoing calls within the profession to focus on changing its negative image. ${ }^{4}$ The public appears to dislike lawyers of all kinds, but it reserves a special contempt for those who represent indigent clients charged with crimes. ${ }^{5}$ After all, public defenders are called upon every day to represent indigents who are accused of murder, rape, kidnapping, robbery, theft, drug usage and distribution, assault, and other conduct that threatens persons and property alike. Many believe that people accused of such crimes do not deserve to have any counsel at all, much less competent, well-trained counsel.

Nevertheless, our adversarial system of law necessitates that we provide adequate assistance of counsel to anyone accused of a crime who cannot afford his or her own representation. ${ }^{6}$ An indigent--even one accused of committing heinous crimes-still has the right to the presumption of innocence and to a fair trial in which he can proffer a defense to the charges leveled against him. Without access to counsel, an innocent individual may be convicted of a crime merely because she happens to be poor. ${ }^{7}$ Providing competent counsel is the best means of ensuring the proper operation of the constitutional safeguards designed to protect the innocent and the less culpable from unfair punishment, including death. ${ }^{8}$ As Justice Black so eloquently recognized in Gideon v. Wainwright:

Our state and national constitutions and laws have laid great emphasis on procedural and substantive safeguards designed to assure fair trials before impartial tribunals in which every defendant stands equal before the law. This noble idea can not be

4. See Karen Dillon, Can The Profession Save Itself?, AM. LAW., Nov. 1994, at 5 (veteran lawyer Sol Linowitz and others discuss the problems of the legal profession and propose solutions to address their concerns).

5. See, e.g., SPECIAL COMMITTEE ON CRIMINAL JUSTICE IN A FREE SOCIETY OF THE AMERICAN bar Association Criminal Justice SECTION, CRIMINAL Justice in CRISIS: A REPORT TO THE AMERICAN PEOPLE AND THE AMERICAN BAR ON CRIMINAL JUSTICE IN THE UNITED STATES 37 (1988); see also Michael McConville, Dilemmas in New Models for Indigent Defense, 14 N.Y.U. REV. L. \& SOC. CHANGE 179, 181 (1986) ("Lawyers for the poor are generally held in low esteem. They are regarded as poor lawyers ....").

6. See, e.g., Lakeside v. Oregon, 435 U.S. 333, 341 (1978) ("In an adversary system of criminal justice, there is no right more essential than the right to the assistance of counsel.").

7. See, e.g., Powell v. Alabama, 287 U.S. 45, 69 (1933), which held:

Left without the aid of counsel he may be put on trial without a proper charge, and convicted upon incompetent evidence, or evidence irrelevant to the issue or otherwise inadmissible. He lacks both the skill and knowledge adequately to prepare his defense, even though he may have a perfect one. He requires the guiding hand of counsel at every step in the proceedings against him. Without it, though he be not guilty, he faces the danger of conviction because he does not know how to establish his innocence.

8. See, e.g., Argersinger v. Hamlin, 407 U.S. 25, 46 (1972) (Powell, J., concurring in the result) ("The interest protected by the right to have guilt or innocence determined by a jury ... is not as fundamental to the guarantee of a fair trial as is the right to counsel."). 
realized if the poor man charged with crime has to face his accusers without a lawyer to assist him. ${ }^{9}$

Without an assurance of adequate assistance of counsel for the indigent, the law draws a line between rich and poor, ensuring a fair trial to those on one side of the line and denying a fair trial to those on the other.

Moreover, failure to provide adequate assistance of counsel to accused indigents draws a line not only between rich and poor, but also between white and black. For the first time in our nation's history, the number of people who are incarcerated in jails and prisons surpasses one million. ${ }^{10}$ Recent reports indicate that unprecedented numbers of African-Americans, particularly young males, are involved in the criminal justice system. ${ }^{11}$ When discussing the inadequacies of the current system of providing counsel for the accused poor, one cannot ignore the correlation between race and poverty. If the criminal justice system deprives the poor generally of the right to a fair trial, that burden will fall disproportionately on communities of color because of the greater incidence of poverty in these communities and, hence, their greater reliance on public defender services.

The debate about public defender services also cannot ignore the fact that the same communities that suffer disproportionately from inadequate provision of legal services to the poor are already subject to peculiar disabilities in the criminal justice system. The most recent wave of criminal justice reforms has included the enactment of laws that appear to be aimed at members of certain races, leading to even higher levels of incarceration of African-American males. One of the most disturbing examples of race-based criminal law reform is the enactment of differing penalties for cocaine convictions based solely on the form in which the cocaine is possessed or distributed.

In Minnesota $v$. Russell, ${ }^{12}$ five African-American males challenged a state criminal prosecution for possession of crack cocaine. The defendants alleged that African-Americans, who constitute ninety-six percent of those charged with possession of crack cocaine, and white Americans, who constitute nearly eighty percent of those charged with possession of powder cocaine, were treated differently in the imposition of penalties for what is essentially the same crime, that is, possession or distribution of cocaine. Under Minnesota law at the time, the sentence for a conviction of possessing five grams of powder cocaine would likely result in probation. Alternatively, the sentence for a conviction of possessing five grams of crack cocaine would ordinarily result in a penalty of ten years imprisonment. Moreover, the data presented at trial by the defendants indicated that an offender convicted of selling a given amount of crack cocaine

9. 372 U.S. 335,344 (1963).

10. See MARC MAUER, AMERICANS BEHIND Bars: A COMPARISON OF INTERNATIONAL RATES OF INCARCERATION 3 (1991).

11. See MARC MaUer, Young Black Men and the CRiminal Justice System: A Growing National Problem (1990).

12. 477 N.W.2d 886 (Minn. 1991). 
would receive the same sentence as would an offender convicted of selling one hundred times that amount of powder cocaine. The Minnesota Supreme Court concluded that the statute failed the rational basis test drawn from the equal protection clause of the state constitution, which in some respects is more stringent than the federal test. ${ }^{13}$

The federal courts have also noted the racial disparity in sentencing for cocaine possession and distribution caused by the dubious distinction drawn between crack and powder cocaine in the federal statutes. For example, Judge Louis Oberdorfer of the District Court for the District of Columbia held in United States $v$. Walls that the statutory mandatory minimum sentences for crack cocaine possession in some circumstances constituted cruel and unusual punishment in violation of the Eighth Amendment. ${ }^{14}$ Federal District Court Judge Clyde Cahill has also commented on the severe impact the disparity between crack and powder cocaine sentencing has had on the African-American community:

While Congress may have had well-intentioned concerns, the Court is equally aware that this one provision, the crack statute, has been directly responsible for incarcerating nearly an entire generation of young black American men for very long periods, usually during the most productive time of their lives. Inasmuch as crack and powder cocaine are really the same drug, ... . it appears likely that race rather than conduct was the determining factor. ${ }^{15}$

Moreover, racial disparity in the federal system is not limited to sentencing for the possession and distribution of crack and powder cocaine; Douglas McDonald and Kenneth E. Carson have documented racial disparity in the application of the Federal Sentencing Guidelines generally. ${ }^{16}$

In spite of the overwhelming evidence of dramatic increases in the arrest, prosecution, and conviction of African-American males, little attention has been given to the impact that improved public defender services would have on these numbers. Public defenders are the only representation to which many of the poor, who are disproportionately members of communities of color, will have access. If public defender services are inadequate, the accused poor will likely be deprived of constitutional procedural protections. Furthermore, constitutional violations arising from the substantive law may also be overlooked, as two of the drug cases mentioned above illustrate. In both Minnesota v. Russell and United States v. Clary, the public defenders representing the defendants were able to bring to light racial disparities in the substantive law that might otherwise have gone unnoticed. ${ }^{17}$ Failure to ensure the adequacy of public defender programs produces a disproportionate impact not only on the poor, but also on members of communities of color, a result that is unacceptable in

13. Id. at 888-89.

14. 841 F. Supp. 24, 25 (D.D.C. 1994).

15. United States v. Clary, 846 F. Supp. 768,770 (E.D. Mo. 1994).

16. See, e.g., DOUglas C. MCDONALD \& KenNETH E. CARSON, SENTENCING IN THE FEDERAL COURTS: DOES RACE MATTER? 1986-1990 (1993).

17. See Clary, 846 F. Supp. at 779; Russell, 477 N.W.2d at 889. 
a society committed, as ours is by the Fourteenth Amendment, to equal treatment under the law.

III

\section{The Challenges of Being a Public Defender}

Many of the difficulties facing public defenders are well documented. The day-to-day work of public defenders is highly stressful because of unwieldy caseloads, uncooperative clients, and an unsupportive criminal justice system. Furthermore, while there is enthusiastic support for providing greater resources to the state to carry out its responsibilities in the criminal justice system, there is very little corresponding support for increasing the resources available to public defenders. These structural burdens on the office of the public defender are exacerbated by intense criticism from both the public in general and the particular clients of public defenders. The lack of institutional support for public defenders-coupled with criticism, often unfair, aimed at them from both sides-takes an enormous psychological toll on those in the profession. In order to understand the challenges faced by public defenders, one must examine the problems of insufficient institutional support, stringent criticism from the public and clients alike, and the psychological stresses resulting from these realities.

\section{A. Lack of Institutional Support}

Unlike most other members of the legal profession, the typical public defender is burdened by a dramatic lack of resources,$^{18}$ limited training and supervision, an unconscionable caseload, ${ }^{19}$ unhealthy working conditions, and unsympathetic police, prosecutors, judges, witnesses, and jurors with whom she must work. A variety of studies of the system indicate that the lack of resources, high caseloads, inadequate training, and tremendous pressure to process cases generate a constant stress on public defenders which leads to an increasing sense of cynicism and disillusionment about the job. ${ }^{20}$ Representation of indigents at the federal level is further complicated by new federal bail and speedy trial requirements, the sentencing guidelines, and mandatory minimum sentences, all of which have increased the pressure on public

18. See, e.g., Letter from Phylis Bamberger, Attorney-In-Charge of the Federal Defender Services Appeals Unit of the Legal Aid Society of New York, to Editor, N.Y. TIMES, Dec. 10, 1985, at A30.

19. See, e.g., State v. Peart, 621 So. 2d 780 (La. 1993) (declaring the New Orleans Indigent Defender Program unable to meet constitutional standards due to high caseloads and inadequate resources); see also Andy Court \& Kevin Bell, Trial Talk: Public Defenders: To The Barricades!, AM. LAW., May 1992, at 99 (suggesting public defenders might have to argue ineffective assistance of counsel before taking cases).

20. See, e.g., LiSA J. McIntyre, The Public Defender: ThE Practice of LAW IN THE SHADOWS OF REPUTE 63-64, 77-91 (1987) (conducting a survey of the attitudes of public defenders in the Cook County Office in Chicago, Illinois, and documenting the cynicism, disillusionment, and burnout experienced in their work). 
defenders, thereby causing a diminished ability to provide adequate representation. ${ }^{21}$

Of all the institutional difficulties faced by public defender offices, perhaps the most daunting is the persistent lack of adequate funding. As the Reporter for the Criminal Justice Act Review Committee, ${ }^{22}$ I received letters and heard powerful testimony from numerous public defenders who explained how their inability to provide effective assistance of counsel was a direct result of the inadequate resources made available to them under federal law. ${ }^{23}$ Judges presiding over cases where the accused is represented by a public defender have also recognized the strain imposed by inadequate funding ${ }^{24}$ and this strain becomes even greater in the more complex cases. ${ }^{25}$ Under the current system, public defenders often lack the funds even to interview clients or witnesses, and they cannot retain experts without prior judicial approval. ${ }^{26}$

\section{B. The Critical Public}

Adding to the stress on public defenders is the low esteem in which the general public holds them. Public defenders are often viewed by the public as either incompetent at what they do $^{27}$ or immoral for doing it. ${ }^{28}$ The hostile public attitude toward public defenders was evident during the recent strike by the Legal Aid Society in New York City. ${ }^{29}$ Mayor Rudolph Giuliani fired the strikers to force agreement on a contract that requires cases to be handled with fewer lawyers and resources, with the predictable consequence that many clients will be lost in the shuffle. ${ }^{30}$ The negative sentiment toward public defenders was made manifest by the public's response to the crisis: public opinion supported Giuliani and condemned the striking Legal Aid workers.

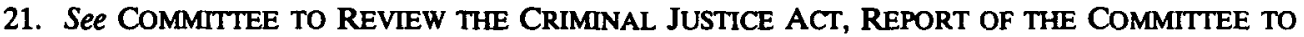
REVIEW THE CRIMINAL JUSTICE ACT (1993), reprinted in 52 Crim. L. Rep. (BNA) 2265 (1993) [hereinafter REVIEW COMMITTEE REPORT].

22. For a detailed presentation of the efforts to study the application of the Criminal Justice Act on the federal level, as well as a list of recommendations for reform, see id.

23. Id.

24. See Peart, 621 So. $2 d 780$.

25. See, e.g., United States v. Rogers, 602 F. Supp. 1332, 1349 (D. Colo. 1985) ("The costs of mounting a defense of an indictment under RICO are far beyond the resources or expertise of the average federal public defender's office which is already over taxed.").

26. See REVIEW COMMITTEE REPORT, supra note 21, at 2275, 2277; see also Fred Warren Bennett, Toward Eliminating Bargain Basement Justice: Providing Indigent Defendants with Expert Services and an Adequate Defense, 58 LAW \& CONTEMP. PROBS. 95 (Winter 1995).

27. See, e.g., Jonathan Casper, Did You Have A Lawyer When You Went to Court? No, I had a Public Defender, YALE REV. L. \& SoC. ACTION, Spring 1971, at 4 (recounting a study of public perceptions of public defenders).

28. See James KunEn, "How Can You Defend Those PEOPle?": The Making of a CRIMINAL LAWYER (1983) (former public defender discussing the public's, as well as his own, reservations about being a public defender).

29. See Jeff Barge, Defenders Seek Parity in Pay, Caseloads, 80 A.B.A. J. 24 (1994).

30. See Abraham S. Blumberg, The Practice of Law as a Confidence Game: Organizational Cooptation of a Profession, 1 LAW \& Soc'Y REV. 15, 38-39 (June 1967). 
Public defenders are criticized at least as much for doing their job well as for doing it poorly. Many criticize the fact that public defenders avail themselves of the law's safeguards in defending a client. For example, two criticisms often leveled at public defenders are that they cross-examine truthful witnesses to make them appear unreliable and move to suppress probative and incriminating evidence against their clients. These criticisms of public defenders are commonplace, despite the recognized importance of such activities to our adversarial system of justice. As Justice Byron White stated unequivocally in United States v. Wade:

[D]efense counsel has no ... obligation to ascertain or present the truth. ... If he can confuse a witness, even a truthful one, or make him appear at a disadvantage, unsure or indecisive, that will be his normal course. Our interest in not convicting the innocent permits counsel to put the State to its proof, to put the State's case in the worst possible light, regardless of what he thinks or knows to be the truth. ${ }^{31}$

\section{The Critical Clients}

Public defenders are the object of unduly harsh criticism not only from the public at large, but even from the clients that they are working so hard to help. Clients' misunderstandings of the criminal justice system often lead them to level unfair charges against their public defenders. For instance, public defenders have been criticized for their close alliance with other court agents, including judges, prosecutors, and police. ${ }^{32}$ They are paid from the same coffers that pay these other court agents, their offices are occasionally housed in the courthouse itself, and they often make deals with prosecutors that send clients to jail. While attorneys tend to realize the necessity of such arrangements, clients many times do not. As a result, they accuse their public defenders of being too integrally involved in the criminal justice system, misidentifying them as players in a nefarious "confidence game." 33

Perhaps as a result of this perception of public defenders as players in a confidence game, clients often lay full blame for the faults of the system at the feet of their public defenders instead of apportioning the blame among the various actors in the criminal justice system. A recent edition of the American Lawyer told the story of an innocent client who spent a year in jail. After the court determined his innocence, his release was delayed another 113 days because the public defender did not file the appropriate form to secure the client's prompt release. The client and his family placed all the blame for the incident on the public defender. As the story recounted, "Houston [the client] didn't get a chance to enjoy a turkey dinner with his sister and his ailing mother. Instead, he remained in jail because of a clerical error and his public defender's inattention." ${ }^{34}$ And as Houston himself wrote in a letter to the judge in his

31. 388 U.S. $218,256-58$ (1967).

32. See Blumberg, supra note 30, at 23-24; see also McConville \& Mirsky, supra note 2, at 582-83.

33. See Blumberg, supra note 30 , at 24.

34. Nicholas Varcharver, Sentenced Before Trial, AM. LAW., Jan./Feb. 1993, at 48. 
case, "[My] lawyer does not seem to be acting in my best interest." 35 In addition, the story explained that when Houston was finally released, it was due to the efforts of a jail chaplain, a court clerk, a reporter-everyone but his public defender. ${ }^{36}$ Although the public defender's nonfeasance in this case was inexcusable, it is telling that the criticism was focused so single-mindedly on the public defender and not at all directed toward the judge, the prosecutor, and the jail warden involved in the case.

Furthermore, structural realities of the current system are bound to generate client hostility toward public defenders. A public defender burdened with inadequate resources and an unreasonable caseload may not even know the client's name-much less the identity of the witnesses and the theories of the case-until the day of the trial itself. In light of the shortcomings of the current system, it is little wonder that poor clients are uneasy about the representation they will receive from lawyers who they do not choose and have little power to remove, and who lack sufficient resources to change their clients' situations. Nevertheless, most failures by public defenders to do their job effectively result from the structure of the criminal justice system rather than from lack of concern by the public defenders. As a whole, public defenders are deeply committed to their work and their clients; therefore, criticism from these same clients inflicts a particularly deep wound.

\section{The Psychological Toll}

In light of the dramatic lack of institutional support public defenders receive and the intense criticism to which they are subjected by both the public and their clients, it is not surprising to find that many public defenders report deep dissatisfaction with their job. However, when these largely exogenous factors combine with the stress inherent in representing the accused, and often guilty, poor, the emotional strain on public defenders can be devastating. Public defenders from across the country offer painful testimony of the physical and emotional toll of doing their jobs. They tell of losing their motivation to be a crusader because they have become jaded, disillusioned, or cynical about the work of public defenders. One public defender described her feelings as follows:

When you become a legal aid lawyer, you think that you are going to be the champion of poor people who are dying to meet you, who are thrilled with your representation, who are innocent victims of society, who are indigent. And then, slowly, these ideals get chipped away. ... Slowly you begin to realize that maybe this prosecutor is not railroading every client, and that maybe, in some cases, your client is guilty. ${ }^{37}$

35. Id. at 53.

36. Id. at 52-54.

37. Paula S. Deutsch, Gideon v. Wainwright's Application in the Courts Today: Gideon's Effect on A Legal Aid Attorney, 10 PACE L. REV. 387, 387 (1990). 
As a result, many leave the field, and their decisions to end their careers as public defenders are adamant and unequivocal. ${ }^{38}$

\section{IV}

\section{PROPOSALS FOR REFORM}

The issues raised during the public hearings held by the Criminal Justice Act Review Committee revealed a startling number of problems that compromise the ability of public defenders to represent their clients effectively. As noted above, public defenders are burdened by limited resources, heavy work responsibilities, and pervasive negative public images of their role. At the hearings, witness after witness, including judges, prosecutors, court-appointed attorneys, and public defenders, offered proposals for meaningful reform. While some of those reforms were accepted by the Judicial Conference, all too many of the reforms were not adopted.

The Supreme Court has long recognized that the right to the assistance of counsel is an evolving concept ${ }^{39}$ and that over time society must reevaluate its meaning. The time has come to redefine the right to counsel to mean that the accused poor should have access to competent counsel who have sufficient resources available to enable them to provide effective representation. The ideal of ensuring competent representation for the indigent by providing adequate resources to public defender services is neither ideological nor partisan. Indeed, the concept of effective representation for indigent defendants is as consistent with the role of prosecutors as it is with the objectives of defense counsel. United States courts have long held that prosecutors must seek justice and not merely convictions. ${ }^{40}$

Of late, judges, ${ }^{41}$ legal scholars, ${ }^{42}$ and policymakers ${ }^{43}$ alike have noted the gravity of the problems facing public defenders. As a result, a number of people with substantial and direct knowledge of the inner workings of the criminal justice system have begun the task of proposing meaningful reforms of our present system. ${ }^{44}$ John D. Cleary, a veteran criminal defense lawyer, offers an impressive alternative to the current incremental approach to solving the

38. See, e.g., Randy Bellows, Notes of a Public Defender, in THE SocIAL RESPONSIBILITIES OF LAWYERS: CASE STUDIES 69, 97 (Philip B. Heymann \& Lance Liebman eds., 1988) ("I find myself burned out, a syndrome which I thought afflicted only other lawyers. I am tired of being a public defender. I am sick of representing so many bad people . . ...").

39. See Argersinger v. Hamlin, 407 U.S. 25, 44 (1972) (Burger, C.J., concurring).

40. See Berger v. United States, 295 U.S. 78, 88 (1935) (Prosecutors have "as much . . . duty to refrain from improper methods calculated to produce a wrongful conviction as ... to use every legitimate means to bring about a just one.").

41. See United States v. Rogers, 602 F. Supp. 1332, 1350 (D. Colo. 1985); State v. Peart, 621 So. 2d 780, 789-90 (La. 1993).

42. See Lefstein, supra note 2, at 392; Mounts, supra note 2, at 481-88.

43. See REVIEW COMMITTEE REPORT, supra note 21 , at 2265.

44. See, e.g., Kim A. Taylor, Reading Between the Lines: Indigent Defense Issues and the Restatement of the Law Governing Lawyers, 46 OKLA. L. REV. 63 (1993); see also John D. Cleary, Federal Defender Services: Serving The System or the Client?, 58 LAW \& CONTEMP. PROBS. 65 (Winter 1995). 
problems facing indigents in criminal cases on the federal level. Cleary advocates the creation of a Federal Defender Services Center with resources comparable to those available to the Department of Justice. The arguments for the Federal Defender Services Center apply with equal force in the context of state criminal justice systems.

In addition to the advantage of greater resources, the proposal for state and federal criminal justice centers offers an opportunity to develop a public defender service that is independent of the judiciary. Many of the arguments for such independent structures are obvious. For example, federal judges cannot possibly understand the defense function or client needs in individual cases and thus should not be in a position to determine who is hired to manage public defender offices, ${ }^{45}$ how resources should be allocated, or what constitutes a valid expenditure. Judicial involvement in Justice Department hiring and spending policies would quickly be denounced as unwise, yet analogous behavior is commonly tolerated between the judiciary and public defender offices. The creation of independent centers would ensure the integrity of the judiciary while protecting the interests of criminal defendants. ${ }^{46}$

\section{$\mathrm{V}$ \\ LESSONS FROM THE D.C. PUblic Defender SERVICE}

Building on Cleary's proposal for reform, I envision independent public defender services centers that would incorporate lessons derived from my own experiences as a public defender in Washington, D.C. During my tenure there, the D.C. Public Defender Service consistently provided competent representation to its clients. The two facets of my experience in the D.C. Public Defender Service that, in my opinion, contributed the most to our ability to provide consistently competent representation were the excellent training provided and the unique culture of the office. I offer the following description of these two facets of my experience in hopes that it can be used as a blueprint for the design of future public defender services.

\section{A. Training in the D.C. Public Defender Service}

An integral component in providing criminal defendants with high quality representation is adequate training and preparation of the attorneys. Unfortunately, precious few public.defender services require such a training program before permitting attorneys to engage in actual representation. Training in the D.C. Public Defender Service included lessons from experts, practical exercises, a focus on thoroughness, ongoing training, and preparation

45. Fred Bennett, Esq., the former chief public defender for the District of Maryland, was removed from his job, and not reappointed, as a direct result of his criticisms of the criminal justice system in general, and the judiciary in particular. See Alison Frankel, Too Independent, AM. LAW., Jan./Feb. 1993 , at 67.

46. See REVIEW COMMTTEE REPORT, supra note 21, at 2287. 
for conducting investigations. I shall explain below how the D.C. Public Defender Service training program encompassed each of these elements.

1. Experts and Practical Training. The involvement of experts in the Public Defender Service training program greatly contributed to its success in preparing attorneys to provide representation. Because of the program's excellent reputation, the agency was able to enlist the assistance of local judges to volunteer time at the end of their busy calendar days to participate in training exercises. A number of experts in such fields as ballistics, fingerprint identification, polygraph examinations, blood and saliva analysis, hair and fiber examinations, and the insanity defense also participated in the training program. By the time new Public Defender Service lawyers had completed the training program, they had been introduced to almost every facet of criminal litigation and had a working knowledge of how to apply this expertise in actual cases.

In addition to the involvement of experts in the training process, the program included practice exercises designed to teach the attorneys how to competently prepare for every case. Before each day's training session, the attorneys were required to read dozens of cases. They were then given the opportunity to put their newly acquired knowledge into practice by drafting motions for suppression and arguing them before local judges against experienced prosecutors. The efficacy of these training exercises was evidenced by the remarkable success Public Defender Service trainees later achieved in winning motions, appeals, and other legal arguments in court.

2. Training for Thoroughness. The training program also emphasized to each attorney the importance of thoroughness. Prosecutors have access to much confidential law enforcement information that is not usually available to defense attorneys. Thus, Public Defender Service attorneys were taught to learn twice as much about every case as the prosecutor. They were taught to prepare thoroughly every case, regardless of the expected outcome. They were trained to review the files of codefendants or others with similar cases to glean useful information concerning trends and practices by police officers in seeking search warrants, the types of plea offers extended by certain prosecutors, and the usual sentences imposed by certain judges. Although only a small percentage of a public defender's caseload actually went to trial, the attorneys were taught to prepare each case as if it were going be tried and as if the client were charged with capital murder.

The success of this emphasis on thoroughness could be seen in how the attorneys actually practiced law. Attorneys from the Public Defender Service routinely applied for every piece of relevant information that law enforcement could conceivably have. They kept abreast of routine police procedures, used discovery of prosecutors, had informal conversations with police officers, and, when appropriate, filed Freedom of Information Act requests. As required by the Service, they thoroughly documented their activities. When meeting with prosecutors to obtain discovery, they followed each session with a letter stating 
what had been received, what was outstanding, and what was promised for the future. They also consistently urged prosecutors, consistent with the rules of evidence, to keep them appraised of any additional information that might be relevant to the case which had not already been received. The training program thus produced attorneys who thoroughly prepared every case and explored every possible avenue for advancing the client's interests.

3. Ongoing Training and Preparation for Conducting Investigations. The success of the training program also depended on the ongoing training that took place after the attorneys had been practicing. The Public Defender Service held bimonthly staff meetings to provide supplemental training to new and senior staff attorneys. The agency also held weekly lunches for attorneys assigned to the juvenile division to keep them abreast of new developments in the law and apprised of changes in court personnel, new programs available for client dispositions, and other resources that might aid in client representation.

Finally, all Public Defender Service attorneys were trained to perform their own investigations. Although the attorneys had access to full-time, permanent investigators and to college students who worked during breaks from school, it was expected that each attorney would ultimately be responsible for the nature and the extent of the investigation in his or her own cases. Each attorney quickly learned the futility of putting an investigator on a case before she had become familiar with the scene of the crime herself, had developed a legal theory and defense, or had already uncovered specific information that would make the investigator's efforts worthwhile. The senior staff attorneys assigned to review the cases and defense strategies did not hesitate to point out instances in which a staff attorney had failed to investigate his case properly.

\section{B. The Office Culture of the D.C. Public Defender Service}

In addition to the excellent training Public Defender Service attorneys received, the culture of the office encouraged the commitment of each attorney to her clients, thereby improving the quality of representation. The Service sought to instill in each attorney an ability to understand and sympathize with the clients by pointing out the social ills that had played a part in bringing the clients to their current situations. Many of the clients were poor, black men who were undereducated, unemployed or underemployed, and products of single-parent families. Some form of drug abuse was often a part of the family history, and a fair share of the clients presented complex mental health issues. It did not take long for a new attorney to come to view his clients in the more sympathetic light of their past sufferings at the hands of society. Greater understanding of the factors that brought these defendants into the criminal justice system in the first place not only generated increased commitment on the part of the public defenders, but also allowed the attorneys to provide more insightful representation in many cases. 
In spite of such sympathy, Public Defender Service attorneys remained well aware of the serious crimes that some clients committed and the significant adverse impact these crimes had on the community. Often the clients and their victims came from the same community, pitting brother against brother, father against son, and neighbor against neighbor. Nevertheless, Public Defender Service attorneys were taught to keep in sight one central goal, namely, to provide the best possible representation for each client by ensuring that all his constitutional rights were vindicated throughout the criminal justice process.

The sense of community within the office of the Public Defender Service also contributed to the high quality of representation provided by its attorneys. Every day, Service lawyers discussed cases and their applications at lunch meetings, during coffee breaks, and during informal social gatherings at the end of the day. The culture of the Public Defender Service encouraged the lawyers to spend virtually all their waking hours thinking about the relevant legal issues. Although one would think that this preoccupation with the law would cause early burnout and cynicism, quite the opposite occurred. Time and time again during the course of late-night skull sessions, lawyers came up with creative arguments that turned out to be persuasive the following day in court. The manner in which Public Defender Service attorneys handled the law, their clients, and their cases provides an excellent model for successful advocacy for the accused poor.

\section{VI \\ CONCLUSION}

The insufficient funding that plagues public defender services programs results in inadequate training and resources. Such structural limitations inhibit public defenders' ability to defend their indigent clients effectively, thereby engendering much criticism from the general public as well as particular clients. Such negative feedback serves to compound the cynicism and psychological stress faced by public defenders. Moreover, the disproportionate presence of racial minorities among the indigents relying on public defender services reinforces the need to ensure that all defendants receive competent representation, else the criminal justice system will create further disparities in treatment of persons of different races.

Many of the problems presently confronting public defender offices can be addressed by creating an independent Defender Services Center, modeled after the Washington, D.C., Public Defender Service, to fund and streamline individual offices. Such a center would focus on providing pervasive ongoing defense attorney training and on developing and sustaining a positive office culture, two techniques proven effective in enhancing the efficacy of the representation of the poor. Without such radical and substantial reform, we will continue to face the persistent problem of denying to those most in need the essential services necessary to ensure that the interests of justice are served. 
